\title{
Forty years literature review of primary lung lymphoma
}

\author{
Haralabos Parissis
}

\begin{abstract}
There are several unresolved issues through out the literature regarding the entity of primary lung lymphoma. Extensive literature review of this uncommon pathology is carried out.

By taking into consideration the reported experience, the author discuss the classification, clinical features, histological differential diagnosis, prognostic criteria, therapeutic management and outcome of primary lung parenchyma lymphocytic infiltrates.
\end{abstract}

\section{Introduction}

Primary Lung Lymphoma (PLL) is a rare entity $(0.4 \%$ of all lymphomas [1] \& $3.6 \%$ of non- Hodgkins lymphomas [2]) of heterogenous group of patients with some common characteristics: 1) difficult to be diagnosed due to an indolent course (with a tendency to relapse) with a non specific clinical and radiological presentation 2) low diagnostic yield and 3) sometimes difficult to differentiate from pseudo-lymphomas and 4)overall good outcome especially in disease amenable to surgical resection.

The main diagnostic criterion for PLL is the absence of extra-pulmonary involvement. That means unilateral or bilateral involvement of the lung with or without hilar or mediastinal lumph node involvement and with or without chest wall involvement [3]. Therefore, in patients with biopsy-proven lymphoma of the lung, PLL is diagnosed if extra-pulmonary involvement is ruled out.

In this article we aim to review the literature in order to delineate from the surgeons prospective, the overall experience of the rare entity of PLL and also to bring up to date the variables leading to a favorable outcome following surgery.

\section{Materials and methods}

Pertinent medical literature in the English language was identified through a Medline computerized literature search and a manual search of selected articles using as Keywords: Primary pulmonary Lymphoma, Lung Lymphoma, Pseudolymphoma of the lung, Non-Hodgkin lymphoma of the lung or extranodal lymphoma. The search terms were

Correspondence: hparissis@yahoo.co.uk

Cardiothoracic Dept, Royal Victoria Hospital, Belfast, Northern Ireland combined using the Boolean operator term "or" to find all abstracts pertaining to the chosen search terms. These individual terms were then combined using the Boolean operator term "and" to find articles that contained information of all search terms (as per Greenhaligh et al) [4]. The reference lists of articles found through these searches were also reviewed for relevant articles. Links provided on the web sites of published articles were searched for relevant articles. The primary search yielded 81 relevant articles. Of those 14 were excluded as they pertained to pseudolymphoma.

The Ann Arbor pulmonary lymphoma staging system was used for classification

\section{Stage}

IE: Lung only, could be bilateral

II 1E: Lung and hilar lymph nodes

II 2E: Lung and mediastinal lymph nodes

II 2EW: Lung \& chest wall or diaphragm

III: lung and lymph nodes below the diaphragm

IV: diffuse

\section{Characteristics of the various reports}

We reviewed the reported literature from 1966 to 2007. We divide the reports into 2 groups. The first group (Table 1 [5-62]) contains case reports with fewer patients compare to the second group (Table 2 [63-71]).

\section{Results}

Group A

58 reports were identified and reviewed. There were 309 cases of PLL. The largest series in this group [58] included 31 patients. 
Table 1 Published Studies with small number of patients nHL: Non Hodgkin Lymphoma MALToma: mucosa-associated lymphoid tissue

\begin{tabular}{|c|c|c|c|c|c|c|}
\hline Author & Year & Journal & Number & $\mathrm{nHL}$ & MALT & Comments/Outcome \\
\hline Gao J [5] & 2002 & $\begin{array}{l}\text { Zhonghua Jie He } \\
\text { He Hu Xi Za Zhi }\end{array}$ & 6 & & & $\begin{array}{l}\text { Misdiagnosis is common. Persistent cough is the most } \\
\text { common symptom }\end{array}$ \\
\hline Zhang L [6] & 2006 & $\begin{array}{l}\text { Zhonghua Wai Ke } \\
\text { Za Zhi }\end{array}$ & 10 & 8 & & $\begin{array}{l}3 \text { cases IE, } 2 \text { cases } \| 1 E, 2 \text { cases } \| 2 E \text { and } 1 \text { case of } \| 2 E W \text {. All } \\
\text { patients had Pneumonectomy \& ChemoTx. Survival }>17 \\
\text { months. Advanced (stage } \| 2 \text { E) B-cell low grade and Hodgkin } \\
\text { disease lead to poor prognosis }\end{array}$ \\
\hline Tian XL [7] & 2008 & $\begin{array}{l}\text { Zhonghua Jie He } \\
\text { He Hu Xi Za Zhi }\end{array}$ & 18 & 7 & 9 & $\begin{array}{l}\text { CT features: nodules } 14 / 18 \text {, Pleural effusion } 5 / 18 \text {. Treatment } \\
\text { with Surgery \& CTx/RTx. Survival > } 11 \text { months: } 13 \text { pts, with } \\
\text { one death and } 4 \text { patients lost to follow up }\end{array}$ \\
\hline Varona JF [8] & 2005 & Tumori & 6 & 6 & & $\begin{array}{l}\text { Mono-CTx treatment with alkylating agents. The authors } \\
\text { suggest that the outcome is favorable whatever the treatment } \\
\text { modalities }\end{array}$ \\
\hline Peterson H [9] & 1985 & Cancer & 6 & 5 & & $\begin{array}{l}\text { Authors suggest that the treatment is surgical resection and } \\
\text { that Rtx and CTx are used when residual disease is present } \\
\text { after surgery. Median time to death:48,6 months }\end{array}$ \\
\hline Muller C [10] & 1990 & Rev Pneumol Clin & 9 & & & $\begin{array}{l}\text { Treatment is surgical in localized forms; there is no firmly } \\
\text { established treatment in extensive forms }\end{array}$ \\
\hline Mu XD [11] & 2007 & $\begin{array}{l}\text { Beijing Da Xue } \\
\text { Xue Bao }\end{array}$ & 1 & & 1 & $\begin{array}{l}\text { MALT with features: consolidation of right middle lobe and } \\
\text { left lower lobe, left pleural effusion with monocytes, } \\
\text { monoclonal protein in the electrophoresis of serum, CD20 } \\
\text { positive }\end{array}$ \\
\hline Natali F [12] & 1984 & Rev Pneumol Clin & 2 & 2 & & $\begin{array}{l}\text { Discussion about PLL related diseases with a varying degree } \\
\text { of malignancy: interstitial lymphocytic pneumonitis ILP, } \\
\text { pseudolymphoma PL, lymphomatoid granulomatosis LYG }\end{array}$ \\
\hline Deng L [13] & 2003 & $\begin{array}{l}\text { Zhonghua Jie He } \\
\text { He Hu Xi Za Zhi }\end{array}$ & 3 & 3 & & $\begin{array}{l}\text { Radiological features of } 3 \text { cases and the role of percutaneous } \\
\text { biopsy }\end{array}$ \\
\hline Nakachi S [14] & 2007 & $\begin{array}{l}\text { Gan To Kagaku } \\
\text { Ryoho }\end{array}$ & 2 & & & 2 cases of PPHodgkinL \\
\hline Martinez RC [15] & 2004 & & 1 & 1 & & PPL presenting as a pulmonary mass with cavitation \\
\hline Colby TV [16] & 1982 & & 20 & $20 ?$ & & \\
\hline Toh HC [17] & 1997 & Leuk Lymphoma & 11 & 11 & & $\begin{array}{l}\text { Mean age 50. Lower lobe involvement was the commonest. } \\
\text { Small lymphocytic lymphoma was the most common. Good } \\
\text { symptom control and radiologic response was achieved with } \\
\text { chemotherapy }\end{array}$ \\
\hline Marchevsky A [18] & 1983 & Cancer & 5 & & & $\begin{array}{l}\text { Criteria for pseudolymphoma Vs PLL. } 167 \text { Cases in the } \\
\text { literature were analyzed }\end{array}$ \\
\hline Morisako T [19] & 1998 & $\begin{array}{l}\text { Nihon Kokyuki } \\
\text { Gakkai Zasshi }\end{array}$ & 6 & 6 & & $\begin{array}{l}\text { Southern blot analysis of lung biopsy: rearrangement of a } \\
\text { heavy chain gene }\end{array}$ \\
\hline Kim JH [20] & 2004 & Jpn J Clin Oncol & 24 & 9 & 15 & $\begin{array}{l}50 \% \text { of the patients were asymptomatic at presentation. } \\
\text { Bronchoscopy: } 30 \% \text { yield, } 67 \% \text { needed surgical procedure for } \\
\text { diagnosis. Overall survival at } 3 \text { years: } 86 \%\end{array}$ \\
\hline Addis BJ [21] & 1988 & Histopathology & 15 & & & The diagnosis was based in 13 cases: on Light chain restriction \\
\hline Arinc S [22] & 2006 & Tuberk Toraks & & & & Review paper on the current approach in PLL \\
\hline Xu HY [23] & 2007 & Chin Med J & 12 & & 12 & $\begin{array}{l}\text { Diagnosis and treatment of MALTomas. } 2 \text { pts also had gastric } \\
\text { MALTS. Operation was performed on } 6 \text { patients. } 4 \text { pts treated } \\
\text { with Chemo alone. Mean survival } 71.3 \text { months. One patient } \\
\text { experience recurrence } 152 \text { months following operation. } \\
\text { Several treatment methods can be used to achieve good } \\
\text { outcomes }\end{array}$ \\
\hline$\underline{\text { Pagani M [24] }}$ & 2007 & Tumori & 1 & 1 & & Single case of right hilar LL. \\
\hline Cao MS [25] & 2008 & $\begin{array}{l}\text { Zhonghua Jie He } \\
\text { He Hu Xi Za Zhi }\end{array}$ & $\begin{array}{l}2 \text { cases of } \mathrm{NKT} \text { cell } \mathrm{L} \text {. } \\
\text { Also Literature review } \\
\text { of } 3 \text { cases }\end{array}$ & & & $\begin{array}{l}\text { Aggressive tumors. Contrary to } \mathrm{nHL} \text { most patients presents } \\
\text { with symptoms. } \\
\text { Pleural effusions } 4 / 5 \text {. Ebstein-Barr was positive in } 3 / 5 \text {. Those } \\
\text { tumors are CD } 56(+), \text { CD3(+) but CD20(-). Most pts died within } \\
6 / 12 \text {. }\end{array}$ \\
\hline Baas AA [26] & 1986 & Eur J Respir Dis & 1 & 1 & & $\begin{array}{l}\text { Single case of a } 49 \text { y old man with multiple ill defined } \\
\text { densities in both lungs treated successfully with } \\
\text { Chemotherapy }\end{array}$ \\
\hline
\end{tabular}


Table 1 Published Studies with small number of patients nHL: Non Hodgkin Lymphoma MALToma: mucosa-associated lymphoid tissue (Continued)

\begin{tabular}{|c|c|c|c|c|c|}
\hline Ziade N [27] & 2005 & J Med Liban & 1 & 1 & Single case of PLL in an elderly patient \\
\hline $\begin{array}{l}\text { Habermann TM } \\
\text { [28] }\end{array}$ & 1999 & Semin Oncol & & & $\begin{array}{l}\text { Review article with an emphasis to observations in the clinical } \\
\text { management and treatment of PLL }\end{array}$ \\
\hline Uematsu M [29] & 1997 & Kyobu Geka & 1 & 1 & PLL of Rt middle lobe treated with lobectomy \\
\hline Tillawi IS [30] & 2007 & Saudi Med J & 2 & & $\begin{array}{l}2 \text { cases of P Hodgkin lymphoma in young patients. CD30 and } \\
\text { CD15 positive in RS cells were detected. }\end{array}$ \\
\hline Chu HQ [31] & 2007 & $\begin{array}{l}\text { Zhonghua Jie He } \\
\text { He Hu Xi Za Zhi }\end{array}$ & 13 & 13 & $\begin{array}{l}\text { MALT is more common in middle age males. Variable } \\
\text { radiographic features; bilateral disease in more than } 50 \% \text { of } \\
\text { the cases }\end{array}$ \\
\hline $\begin{array}{l}\text { Le Tourneau A } \\
\text { [32] }\end{array}$ & 1983 & Hamatol Oncol & 15 & 15 & $\begin{array}{l}\text { Reference to Kiel- Lennert histo pathological classification. } \\
\text { Association of PLL of B type and dysimmune disease }\end{array}$ \\
\hline Loh KC [33] & 1994 & $\begin{array}{l}\text { Ann Acad Med } \\
\text { Singapore }\end{array}$ & 3 & 3 & $\begin{array}{l}\text { Interestingly, despite nodal involvement all patients had } \\
\text { surgical resections and adjuvant ChTx. All } 3 \text { alive at 92, } 51 \text { and } \\
12 \text { months }\end{array}$ \\
\hline Cordier JF [34] & 1984 & Rev Mal Respir & 4 & & $\begin{array}{l}\text { The article raises the possible hypothesis that } \\
\text { pseudolymphoma may be the initial step in a large spectrum } \\
\text { ranging from benign to malignant primary lymphoproliferative } \\
\text { lung disorders }\end{array}$ \\
\hline Watanabe J [35] & 1987 & Jpn J Med & 1 & 1 & $\begin{array}{l}\text { The diagnostic value of surface marker analysis in primary B } \\
\text { cell lung lymphoma is emphasized }\end{array}$ \\
\hline Toishi M [36] & 2004 & Kyobu Geka & 2 & 2 & $\begin{array}{l}\text { Report of } 2 \text { cases of MALToma treated with Surgery and post } \\
\text { op RadioTherapy }\end{array}$ \\
\hline Jayet A [37] & 1980 & Helv Chir Acta & 10 & & $\begin{array}{l}\text { This report emphasizes the fact that surgical treatment of PLL } \\
\text { has to be "economical" due to the fact that frequent } \\
\text { recurrences (sometimes bilateral) could be encountered }\end{array}$ \\
\hline Kuroishi S [38] & 2003 & $\begin{array}{l}\text { Nihon Kokyuki } \\
\text { Gakkai Zasshi }\end{array}$ & 1 & 1 & $\begin{array}{l}\text { A case of a lingular lobe PLL that relapsed with diffuse } \\
\text { micronodular pattern } 7 \text { years following surgical resection }\end{array}$ \\
\hline Sakula A [39] & 1979 & Postgrad Med J & 1 & 1 & A single case report \\
\hline Hashizume T [40] & 1997 & $\begin{array}{l}\text { Nihon Kyobu } \\
\text { Shikkan Gakkai } \\
\text { Zasshi }\end{array}$ & 1 & 1 & $\begin{array}{l}\text { A single case report of PLL presented with bilateral infiltrative } \\
\text { shadows }\end{array}$ \\
\hline $\begin{array}{l}\text { Gouldesbrough } \\
\text { DR [41] }\end{array}$ & 1988 & Histopathology & 1 & & $\begin{array}{l}\text { A single case of PLL diagnosed by bronchial cytology and } \\
\text { immunocytochemistry }\end{array}$ \\
\hline Bosanko CM [42] & 1991 & $\begin{array}{l}\text { J Comput Assist } \\
\text { Tomogr }\end{array}$ & 1 & 1 & $\begin{array}{l}\text { A single case report presented as an asymptomatic chronic } \\
\text { lobar consolidation }\end{array}$ \\
\hline Chee YC [43] & 1986 & $\begin{array}{l}\text { Ann Acad Med } \\
\text { Singapore }\end{array}$ & 1 & & $\begin{array}{l}\text { Report of a Pseudolymphoma case with a biclonal } \\
\text { gammopathy }\end{array}$ \\
\hline $\begin{array}{l}\text { Bolton- Maggs PH } \\
{[44]}\end{array}$ & 1993 & Thorax & 2 & 2 & $\begin{array}{l}\text { Report of } 2 \text { cases of MALTomas, giving emphasis on the } \\
\text { varied clinical and radiological features }\end{array}$ \\
\hline Xu TR [45] & 1987 & $\begin{array}{l}\text { Zhonghua Jie He } \\
\text { He Hu Xi Za Zhi }\end{array}$ & 2 & 2 & $\begin{array}{l}\text { Report of } 2 \text { cases of MALTomas, giving emphasis on the } \\
\text { varied clinical and pathological features }\end{array}$ \\
\hline Konig G [46] & 1986 & Prax Klin Pneumol & 1 & & The role of $B A L$ in diagnosis of $P L L$ \\
\hline Ehrenstein F [47] & 1966 & $\begin{array}{l}\text { J. Thorac } \\
\text { Cardiovasc Surg }\end{array}$ & 2 & 2 & 2 cases of PLL \\
\hline Tamura A [48] & 1995 & Jpn J Clin Oncol & 24 & 24 & $\begin{array}{l}\text { PLL: relationship between clinical features and pathologic } \\
\text { findings Pulmonary LL were divided into } 4 \text { groups Bcell } \\
\text { tumors composed of small to medium size lymphoid cells } \\
\text { have the best prognosis }\end{array}$ \\
\hline Sakuraba M [49] & 2000 & $\begin{array}{l}\text { Nihon Kokyuki } \\
\text { Gakkai Zasshi }\end{array}$ & 3 & 2 & Report of 3 cases \\
\hline Abe $Y[50]$ & 1998 & $\begin{array}{l}\text { Nihon Kokyuki } \\
\text { Gakkai Zasshi }\end{array}$ & 1 & 1 & $\begin{array}{l}\text { One case of MALToma diagnosed with flow cytometer } \\
\text { analysis, monoclonal gammopathy and Southern blot analysis } \\
\text { of the heavy chain of the immunoglobulin gene }\end{array}$ \\
\hline Umino T [51] & 1993 & $\begin{array}{l}\text { Nihon Kokyuki } \\
\text { Gakkai Zasshi }\end{array}$ & 1 & 1 & $\begin{array}{l}\text { A case of PLL diagnosed with: High serum IgG, BAL showing } \\
45 \% \text { plasma cells and } 18 \% \text { lympocytes, CD19(+), IgG/albumin } \\
\text { ratio } 13 \text { times higher and IL-6/albumin ratio } 29 \text { times higher in } \\
\text { BAL than serum. The PCR on the DNA extracted from the } \\
\text { surgical specimen showed rearrangement of the } \\
\text { immunoglobulin heavy chain gene }\end{array}$ \\
\hline
\end{tabular}


Table 1 Published Studies with small number of patients nHL: Non Hodgkin Lymphoma MALToma: mucosa-associated lymphoid tissue (Continued)

\begin{tabular}{|c|c|c|c|c|c|}
\hline Zinzani PL [52] & 2003 & & 12 & & MALTomas \\
\hline Herbert A [53] & 1984 & Hum Pathol & 9 & 9 & $\begin{array}{l}\text { The authors claim that histologic evidence of lymph node } \\
\text { involvement is unusual even in the presence of mediastinal or } \\
\text { pleural infiltration }\end{array}$ \\
\hline Davis WB [54] & 1987 & Chest & 1 & 1 & $\begin{array}{l}\text { Report of one case of bilateral interstitial infiltrates with } \\
\text { lymhocytic alveolitis on the BAL }\end{array}$ \\
\hline Pisani RJ [55] & 1990 & Mayo Clin Proc & 1 & 1 & $\begin{array}{l}\text { Report of the first case wherein PLL was diagnosed with } \\
\text { immunohistologic (less diagnostic for T cell lymphomas) and } \\
\text { molecular biologic studies of BAL. }\end{array}$ \\
\hline Sprague RI [56] & 1989 & Chest & 1 & & $\begin{array}{l}\text { A case of an elderly female with multiple densities on CXR. } \\
\text { Diagnosis was made with transthoracic fine needle aspiration }\end{array}$ \\
\hline Julsrud PR [57] & 1978 & Radiology & & & $\begin{array}{l}\text { Pseudolymphoma \& lymphocytic interstitial pneumonitis have } \\
\text { a different radiographic pattern to lymphocytic lymphoma }\end{array}$ \\
\hline Lewis ER [58] & 1991 & $\begin{array}{l}\text { AJR Am J } \\
\text { Roentgenol }\end{array}$ & 31 & & $\begin{array}{l}\text { CT findings of pulmonary lymphoma: masslike consolidation } \\
(68 \%) \text {, multiple nodules ( } 55 \%) .2 / 3 \text { of the patients have more } \\
\text { than one type of CT finding simultaneously }\end{array}$ \\
\hline Bellotti M [59] & 1987 & Respiration & 5 & & $\begin{array}{l}\text { Report a series of } 5 \text { PLL out of } 9 \text { lymphomas involving the } \\
\text { lung }\end{array}$ \\
\hline Kilgore TL [60] & 1983 & Chest & 4 & & $\begin{array}{l}4 \text { cases of endobronchial } \mathrm{nHL} \text {. The authors claim that all the } \\
\text { patients had disseminated disease at the time of } \\
\text { endobronchial involvement. }\end{array}$ \\
\hline Rose RM [61] & 1986 & Cancer & 3 & & $\begin{array}{l}3 \text { cases of endobronchial nHL. The authors have identified } 2 \\
\text { patterns of endobronchial involvement: Type } 1 \text { characterized } \\
\text { by submucosal infiltrates occurring in the presence of } \\
\text { disseminated disease and Type } 2 \text { whereby the central airway } \\
\text { is involved by a solitary mass in the absence of disease } \\
\text { elsewhere. }\end{array}$ \\
\hline Oka M [62] & 1988 & Am Rev Respir Dis & 1 & & $\begin{array}{l}\text { A case report, whereby the diagnosis of PLL was made } 5 \text { years } \\
\text { after initial presentation }\end{array}$ \\
\hline
\end{tabular}

Non Hodgkin Lymphomas (nHL) consist the majority of PLL with mucosa-associated lymphoid tissue (MALTomas) being 70-80\%. Hodgkin lymphoma was reported in a small number of cases $1.5-2.4 \%$.

The course of the disease is long and indolent spanning from 1.5 to 108 months [31].

Radiological appearance have shown that non specific patchy opacities or mass-like consolidation was the case in the majority of the patients (up to 68\%) and multiple nodules in more than $50 \%$ of the cases. $[31,57,58]$.

Nodal involvement (stage II1E, II2E) was reported in $35 \%-45 \%$ of the cases $[6,18,58]$.

Bronchoscopy obtained a diagnostic yield in 30\%-40\% $[20,48]$ of the cases and invasive surgical procedure revealed the diagnosis in up to $70 \%$ of the cases [20].

There was no uniform protocol throughout the literature regarding the indications for surgery. Despite nodal involvement (stage II $1 \mathrm{E}$ and $2 \mathrm{E}$ ) surgery was advocated in few studies [33] and some authors concluded that several treatment methods can be used to achieve good outcomes [23].

\section{Group B}

The second group consisted of 506 reported cases of PLL.
In the majority of the studies the male to female ratio is variable (from $1 / 1$ [68] to $1 / 2$ [70]). Average age of disease presentation is $53 \pm 12$ years $[65,68-70]$. $83 \%$ of the patients have been reported to be above 40 years of age [65].

Symptoms are present in $2 / 3$ of the patients $(62.5 \%$ to $78 \%$ of patients) $[69,70]$. The mean duration of symptoms was 5 months [65]. Mild symptoms with no resolving consolidation should be managed with a high index of suspicion.

Again, nHL consist the majority of PLL with MALTomas being 60-78\% [69-71].

The radiographic appearance shows nodules or mass lesions in $60-72 \%$, [69,70]. Single lesions are present in $55 \%$ of the cases [65]. Multiple nodules are present in $40 \%$ of the patients $[65,67]$. Bilateral disease varies in different reports: 21\%. [68], 27\% [65], 39\% [70], 44\% [69].

Nodal involvement (stage II1E, II2E) was reported in 28 to $39 \%$ of the cases $[65,69]$ and Pleural effusions $15-22 \%[69,70]$.

There was again, no uniform protocol throughout the literature regarding the indications for surgery. Nevertheless, surgery was advocated in $60-70 \%$ of the patients. The MALToma patients tend to have complete 
Table 2 Published Studies with large number of patients

\begin{tabular}{|c|c|c|c|c|c|c|c|}
\hline Author & Year & Journal & $\begin{array}{l}\text { Number of } \\
\text { Patients }\end{array}$ & & Characteristics & Appearance & Recurrence \\
\hline \multicolumn{8}{|l|}{ Survival } \\
\hline Koss MN [63] & 1983 & Hum Pathol & $\begin{array}{l}161 \text { 14\% } \\
\text { pseudolymphomas }\end{array}$ & $\begin{array}{l}138 \mathrm{nHL} \text {. } \\
\text { Elderly, mainly } \\
\text { asymptomatic }\end{array}$ & $\begin{array}{l}\text { Most cases: Solitary } \\
\text { nodule or infiltrate }\end{array}$ & $\begin{array}{l}\text { Most recurrences } \\
\text { occur within } 3 \\
\text { years }\end{array}$ & $\begin{array}{l}18 \text { out of } 101 \text { patients } \\
\text { died from tumor. Pleural } \\
\text { effusion was a predictor } \\
\text { of mortality }\end{array}$ \\
\hline Turner RR [64] & 1984 & Cancer & 47 & $\begin{array}{l}28 \text { cases of } \\
\text { PLL }\end{array}$ & & & $\begin{array}{l}\text { Good prognosis: } 1 \\
\text { patient died in } 4 \text { years } \\
\text { follow up }\end{array}$ \\
\hline L Hoste R [65] & 1984 & Cancer & $36 \mathrm{nHL}$ & $\begin{array}{l}\text { Mean age } 53 \\
y \text {. More than } \\
80 \% \text { of } \\
\text { patients }>40 y\end{array}$ & $\begin{array}{l}\text { Single lesions } 20 \text { cases. } \\
\text { Multiple: } 16 . \text { Unilateral } \\
\text { 26, bilateral 10. IE:24, } \\
\text { ||1E:2, II2E:8, II2EW:2 } \\
\text { 58\% LPI }\end{array}$ & $\begin{array}{l}33 \% \text { of } L P I \text { recur. } \\
50 \% \text { of non LPI } \\
\text { recur. Average } \\
\text { time to } \\
\text { recurrence: } 69 \\
\text { months }\end{array}$ & $\begin{array}{l}33 \% \text { died, most non LPI. } \\
\text { No survival difference } \\
\text { among cases grouped } \\
\text { according to stage(IE Vs } \\
\text { IIE). For stage IE LPI } \\
\text { group did better. } 5 \text { years } \\
\text { survival } 57 \%\end{array}$ \\
\hline $\begin{array}{l}\text { Kennedy JL } \\
{[66]}\end{array}$ & 1985 & Cancer & $\begin{array}{l}64 \text { pts with } \\
\text { lymphoid lesions } \\
\text { of lung }\end{array}$ & $\begin{array}{l}12 \text { patients } \\
\text { with primary } \\
\text { lymphoma }\end{array}$ & $\begin{array}{l}\text { Heterogenous group of } \\
\text { patients }\end{array}$ & & $\begin{array}{l}\text { Median survival of } 117 \\
\text { months if PLL. For } \\
\text { Disseminated lymphoma } \\
\text { median survival } 33 \\
\text { months }\end{array}$ \\
\hline Li G [67] & 1990 & Histopathology & $\begin{array}{l}62 \text { cases. All B cell } \\
\text { but } 2 \text { cases of T- } \\
\text { cell lymphoma }\end{array}$ & $\begin{array}{l}43 \text { cases of } \\
\text { MALT }\end{array}$ & $\begin{array}{l}32 \text { of the MALTS } \\
\text { showed solitary or } \\
\text { multiple sharply defined } \\
\text { nodules }\end{array}$ & $\begin{array}{l}\text { Recurrences in } \\
46 \% \text { of the MALTS }\end{array}$ & $\begin{array}{l}\text { Constitutional symptoms } \\
\text { and T cell lymphoma } \\
\text { showed a bad prognosis. }\end{array}$ \\
\hline $\begin{array}{l}\text { Cordier JF } \\
\text { [68] }\end{array}$ & 1993 & Chest & $\begin{array}{l}70 \mathrm{nHL}, \text { no } \\
\text { mediastinal } \\
\text { adenopathy }\end{array}$ & $\begin{array}{l}\text { Mean age } 58.4 \\
\text { y, M:F 1:1, } \\
\text { majority non } \\
\text { smokers. } 87 \% \\
\text { Low grade. } \\
\text { majority } \\
\text { MALTs. } 13 \% \\
\text { high grade }\end{array}$ & $\begin{array}{l}\text { Localized opacities } 87 \% \text {. } \\
\text { Mass -like appearance } \\
24 \% \text {, Bilateral disease } \\
21 \% \text {. Monoclonal } \\
\text { gammopathy } 30 \% .\end{array}$ & $\begin{array}{l}\text { Metastasis } 7 \text { pts } \\
\text { (stomach, bone } \\
\text { marrow, spleen, } \\
\text { liver) interval } \\
\text { between Dx and } \\
\text { mets from } 10 \\
\text { months to } 7 \text { years }\end{array}$ & $\begin{array}{l}69 \% \text { underwent surgical } \\
\text { resection. Overall survival } \\
93.6 \% \text { at } 5 \text { years for low } \\
\text { grade } L 26 \% \text { treated with } \\
\text { chemotherapy alone }\end{array}$ \\
\hline Ferraro P [69] & 2000 & $\begin{array}{l}\text { Annals of } \\
\text { Thorac Surg }\end{array}$ & $48 \mathrm{nHL}$ & $\begin{array}{l}\text { MALTs } 73 \% . \\
\text { Mean age } 61.8 \\
\text { years. } \\
\text { Symptoms } \\
62.5 \% \text { of } \\
\text { patients, }\end{array}$ & $\begin{array}{l}\text { Mass lesion } 60 \%, \\
\text { Bilateral disease } 44 \% \text {. } \\
\text { Mediastinal-hilar } \\
\text { lymphadenopathy } 31 \% \text {. } \\
\text { Pleural effusions } 15 \% \text {. } \\
\text { IE: } 37 \text { patients, II2E:7, } \\
\text { II2EW:3, Stage III:1 }\end{array}$ & $\begin{array}{l}\text { Local recurrence } \\
50 \%\end{array}$ & $\begin{array}{l}\text { Complete surgical } \\
\text { resection } 40 \% \text { overall. } \\
\text { Incomplete resection in } \\
29 \text { patients ( } 21 \text { patients } \\
\text { with bilateral disease) } \\
73 \% \text { of MALTs had } \\
\text { complete resection. Post } \\
\text { op Chemo } 54 \% \text {. Five } \\
\text { year survival for MALTs } \\
68 \% \text { and } 10 \text { years } 53 \% . .\end{array}$ \\
\hline $\begin{array}{l}\text { Graham B } \\
\text { [70] }\end{array}$ & 2005 & $\begin{array}{l}\text { Annals of } \\
\text { Thorac Surg }\end{array}$ & 18 & $\begin{array}{l}\text { MALTs } 78 \% . \\
\text { Mean age } 66.4 \\
\text { y M:F } 1: 2 \\
\text { Symptoms } \\
78 \% \text { of } \\
\text { patients, }\end{array}$ & $\begin{array}{l}\text { Nodules or Mass lesions } \\
72 \% \text {, Bilateral disease } \\
\text { 39\%. Mediastinal-hilar } \\
\text { lymphadenopathy 39\%. } \\
\text { Pleural effusions 22\%. } \\
\text { IIE (39\%) pts. }\end{array}$ & $\begin{array}{l}\text { Median time to } \\
\text { disease recurrence } \\
\text { or death: } 6 \text { years }\end{array}$ & $\begin{array}{l}6 \% \text { died of disease. Five } \\
\text { year survival }>80 \%\end{array}$ \\
\hline $\mathrm{Hu}$ YH [71] & 2009 & Ann Hematol & 22 & MALTs 54\% & $\begin{array}{l}\text { Nodules or masses } 73 \% \text {. } \\
\text { Mediastinal } \\
\text { lymphadenopathy } \\
\text { MALTs/non-MALTs: } 8 / 80\end{array}$ & & $\begin{array}{l}\text { Patients who had surgery } \\
\text { tended to have better } \\
\text { survival. Five year survival } \\
\text { MALTs/Non-MALTs } 91 \% \\
\text { over } 21 \% \text {. }\end{array}$ \\
\hline
\end{tabular}

resections. Broadly speaking, following surgery, patients had more favorable outcome [71].

\section{Diagnosis}

The role of monoclonal protein in the electrophoresis of serum protein: ie. Serum IgG $>5000 \mathrm{mgr} / \mathrm{dl}$ has been stated in some reports $[19,21,51]$. Stained for Kappa \& Lambda chains, using the immunoperoxidase technique on paraffin sections has been reported. Serum protein electrophoresis abnormalities could be present in up to $33 \%$ of the cases [65]. Serum or immunofluorescence monoclonal gammopathy should exclude pseudoL. 
Furthermore the presence of a serum monoclonal gammopathy is associated with worse prognosis [66].

The significant role of Broncho Alveolar Lavage (BAL) with a cell count of plasma cells of $40 \%$ and lymphocytes of $17 \%$ with prominence of CD19 positive lymphocytes has been reported by Umino et al [51]. IgG/albumin ratio 13 times higher and IL-6/albumin ratio 29 times higher in lavage fluid than in serum. Furthermore TBLB and immunohistochemical stains mainly CD20 could be helpful. DNA extraction from the surgical specimen and PCR reveals rearrangement band of the genes to the heavy chain immunoglobulin (Fr3a \& VLJH primers) [51]. The diagnostic value of Cell surface markers analysis using fresh tissue was also stated in some reports [35,65].

Staging workup should include bone marrow biopsy and CT of the abdomen to exclude extrathoracic disease. Lymphangiograms and bone scans could be part of the preoperative staging [65].

The role of PET scan is equivocal due to the low avidity and the multifocal nature of the disease. The low yield of bronchoscopy and Transcutaneous needle CT guided biopsy has been stated in few reports $[13,20]$. There is however, a high role for VATS or open surgical lung biopsy with a diagnostic yield more than $90 \%$.

\section{Histology}

PLL arises from centrocyte-like cells normally present in bronchus associated lymphoid tissue. Monomorphic cell population and invasion of bronchial cartilage, pleura or lymph nodes are suggestive of malignancy. Some cases of PLL appeared as complications of a pre existing dysimmune disease (Pigeon breeder disease), GougerotSjogren, Lymphomatoid granulomatosis (LYG) and Liebows lymphomatoid granulomatosis) [12,19,32].

The gross classification of Low Grade malignant Lymphoma higher grade MALTomas (large cell type) and others (ie. Follicular, Diffuse large B-cell, anaplastic large cell)

has been used through out the literature. A detail attempt to estimate the biological potential of lymphomas by their histologic type and correlate this with outcome was attempted with the use of various systems of histologic classification of non Hodgkins lymphomas.

Although from the surgeons prospective the classification seems complicated, one could grossly divide the tumors into small round lymphocytes (50-60\%), with varying degrees of plasmacytic change, ("plasmacytoid" well differentiated) and large lymphocytic tumors.

More specifically the Kiel classification [32] essentially differentiates Lymphoplasmacytic (LP) from Centroblastic lymphoma (CB). The LP type is the most common (55-65\%) [65]. The tumor is composed of uniform small round lympocytes; they often grow as solid masses; infiltration of bronchial and vascular wall is often however necrosis does not present. The incidence of recurrence is less than 35\% through out the literature [65].

Contrary CB type makes up $40 \%$ of the cases. It consists of a centrocytic diffuse or follicular population including the rare immunoblastic type. In general those tumors are aggressive, present as pulmonary infiltrates therefore are not amenable to surgical resection and have a higher tendency to recur.

The term MALTomas was described by Bienenstock et al [72]. They are the most common amongst nHL (76\% according to Cordier et al). The MALTomas are characterized by: extranodal, small lymphocytic b-cell tumor, cellular heterogeneity, infiltration of the bronchial mucosa by centrocyte cells and presence of reactive lymphoid follicles. The etiology of this mucosal transformation is probably acquired in response to longterm exposure to various antigenic stimuli; Synchronus MALTomaS involving the lung, stomach \& ocular adnexa have been reported in the literature [68,70].

Pulmonary lymphomas of $\mathrm{nH}$ type could be divided into 4 groups [48] according to the properties and behavior of the tumor: B-cells small or medium size (those tumors are frequently associated with consolidations and air bronchograms), B-cell large lymphoid cell (frequently radiologic presentation is consistent with a mass) and T-cell tumors (bad prognosis). Furthermore the REAL classification sums up the histological variations of all types of lymphomas [73] however, from the surgical prospective it is detailed and probably not widely applicable.

\section{Differentiating between Lymphoma (especially Lymphoplasmacytic (LP) type) and pseudolymphoma} Mixture of mature lymphocytes and plasma cells with reactive follicles are suggestive of pseudolymphoma.

Pulmonary pseudolymphoma is a rare lesion; Up till 1980 , only 30 cases were reported in the literature. True lymphoma was developed in four cases [34].

The diagnosis of pseudolymphoma is based on: 1) pulmonary nodules composed of cytologically benign lymphoid cells 2) presence of infiltrates with plasma cells, histiocytes and monocytes 3 ) presence of germinal centers. In addition, the presence of pleural effusion does not preclude the diagnosis of pseudolymphoma.

Immunological studies aim to define whether the lymphoid proliferation is monoclonal or polyclonal. It is suggested that PPL arises from centrocyte-like cells normally present in bronchus -associated lymphoid tissue. In addition to malignant population reactive follicles and polytypic plasma cells are frequently present so one should be aware that cases previously diagnosed as pseudo-lymphoma or lymphoid interstitial pneumonia need to be reconsidered. Moreover when recurrent tumors are present then pseudo L is rare; however 
pseudolymphomas do not necessary follow a benign course [18].

\section{Surgical Treatment strategies}

Resection rate varies from series to series $[18,37,68,69]$. There are no guidelines as to when surgery is indicated. While reviewing the literature one gets the impression that surgery is advocated on an institutional basis.

Surgery for solitary lesions and adjuvant therapies for more extensive disease has been the general consensus. Overall $60-70 \%$ of the patients with PLL are surgical candidates [68]; however, incomplete resection is reported to be the case in more than $50 \%$ of the cases [69]. Surgical candidate could potentially be any patient with locally resectable tumor up to stage II $2 \mathrm{EW}$. Lymph node involvement does not appear to be a contraindication to surgery. Likewise bilateral disease could also be tackled surgically. However the surgical ablation of such lesions must be economical [37] because of frequent recurrence, sometimes bilateral. $\mathrm{Hu}$ et al [71] concluded that patients who had received surgery tended to have a better 5 year overall survival.

The MALTomas are slow growing tumors with an indolent course; tent to be localized and therefore amenable to surgery $(73 \%$ complete resection was achieved [69]).

Combined modality therapy appears to be superior in patients with bulky disease, residual disease following operation and an unfavorable non-MALT type of histology.

\section{Recurrence rates}

Pulmonary recurrences are either within the ipsilateral lung or in both lungs. Extrapulmonary recurrent disease occurs mainly in lymph nodes, however skin, bone marrow or visceral organs could be affected $[63,65]$.

The overall local recurrence rate is 50\% [69]. More specifically the incidence of recurrence for the LP group is 33\% with an average time of 69 months versus $50 \%$ for the CB group [65].

The median time to disease recurrence or death has been reported to be 6-7 years $[70,68]$. Late recurrences up to 14 years have also been reported [23].

There are not enough data in the literature regarding Surgery for recurrences; nevertheless the general consensus dictates that recurrences should be treated with aggressive chemotherapy regimes.

\section{Survival data}

This is a heterogenous group of patients. Nevertheless the overall reported median time to death was 7 years or the overall reported mean survival was 71.3 months. More specifically for low grade lymphomas the median survival was 117 months and for disseminated lymphoma 33 months according to Kennedy et al [66].

The overall survival at 3 years was $86 \%$ and at 5 years $57 \%[68,65]$. For the MALTomas the five year survival was $68 \%$ and the ten year $53 \%$ [69].

The prognostic factors influencing survival are: the histologic type, T cell lymphoma [67] the presence of pleural effusion [63] as well as bilateral disease and the need for adjuvant therapy [70]. In contrary according to Ferraro et al [69] complete Vs incomplete resection, the stage of the disease, the presence of mediastinal lumph node involvement or bilateral disease did not significantly influence survival.

\section{Discussion}

Extensive literature review of the medical literature the last 40 years was carried out. We have excluded cases of primary pulmonary AIDS related lymphoma and lymphoma following immuno-suppression and transplantation (200 fold higher than the general population).

The incidence of PLL has two peaks: the first on in the fifth decade of life and the second late six and seventh decade. The diagnostic criteria for PLL include bilateral pulmonary lesions as PPL. The reason for that is the fact that several of those patients when treated never showed evidence of extapulmonary involvement. Also the definition includes absence of extrapulmonary disease for 3 months following the initial diagnosis. This is because invariably extrathoracic and extranodular lymphoma may present (ie. Pulmonary and stomach Lymphoma)

High index of suspicious facilitates the diagnosis of this rare, indolent disease. One third of patients have no symptoms, furthermore out of the symptomatic cohort the duration of symptoms prior to the diagnosis is at least 5 months. Serum protein electrophoresis abnormalities are present in 33\% of the patients [65].

The frequency of imagine features of PLL is difficult to assess in the literature because of varying radiological terminology \& heterogeneity of several series including all lymphomas of the lung. The radiography is non informative (solitary nodule, multiple ill defined nodules, consolidated mass with air bronchograms, ground glass opacity or reticular lesions in one or both lung fields, pleura effusions, atelectasis and cavities) and non specific. Multiple lesions can be present in up to $25 \%$ of the patients [65], air space consolidation with air bronchograms is the most frequent imaging in up to $65 \%-70 \%$ of the cases and pleural effusions in $25 \%$ of the cases [31].

The histological classification having kept the principles of low grade ( $87 \%$ of the patients, as per Cordier et al [68]) and high grade disease, has evolved into more complex classifications taking into account the cell 
morphology and histological characteristics. Although, that does not necessarily correlate with prognosis the gross differentiation into MALTs and non MALTs somehow reflects prognosis [71].

The Staging systems considers bilateral pulmonary lesion as stage I disease and stage II as disease confined to the thoracic cavity;

Only surgical biopsy and resection obtains high yield (64\% of the patients as per Cordier et al [68] \& 90\% of the patients as per Ferraro et al [69].

The prognostic factors affecting survival are not well defined; the stage of the disease, extend of resection (complete Vs incomplete) and the presence of mediastinal lymphadenopathy does is not associated with worse prognosis [69]. In contrary, the report by $\mathrm{Hu}$ et al [71] suggested that hilar or mediastinal node involvement negatively influences survival. Higher stage disease was associated with statistically not significantly worse outcome according to Graham et al [70]. The authors reported that bilateral disease was the most significant factor predicting disease recurrence and death.

The evaluations of the role of surgery as well as the indications for surgery are scarce in the literature; positive surgical margins do not alter survival therefore the role of surgery may be applicable in the majority of the cases following by chemotherapy.

The long term outcome of PLL is favorable; $56 \%$ of the patients recovered from the disease [70] with an overall 5 year survival across the border of $>60 \%$ and a recurrence rate of less than $50 \%$.

During the analysis of the presented series we observed a low consistency in publishing specific variables (ie. Incidence of recurrence, etc) and this precluded us from carrying out detailed statistics; therefore our paper carries the biases not only from the studies examined but also from its observational character. Nevertheless, we believe that our report has attempted to give an insight in this rare and not well addressed pathology.

\section{Competing interests}

The authors declare that they have no competing interests.

Received: 4 November 2010 Accepted: 3 March 2011 Published: 3 March 2011

\section{References}

1. Rosenberg SA, Diamond HD, Jaslowitz B, Craver LF: Lymphosarcoma: A review of 1269 cases. Medicine 1961, 40:31-84.

2. Freeman C, Berg JW, Cutler SJ: Occurrence and prognosis of extranodal lymphomas. Cancer 1972, 29:252-260

3. Saltzstein SL: Pulmonary malignant lymphomas and pseudolymphomas: Classification, therapy and prognosis. Cancer 1963, 16:928-955.

4. Greenhaligh, et al: How to read a paper: the MEDLINE database. Br Med J 1997, 315:180-183.
5. Gao J, Huang X, Wang R, Cai B, Lu W, Lin Y: Primary pulmonary lymphoma: analysis of cases and review of the literature. Zhonghua Jie He He Hu Xi Za Zhi 2002, 25(8):484-7.

6. Zhang LB, Sun YE, Yu CH, Liu Y: Clinical diagnosis and surgical treatment of primary pulmonary lymphoma. Zhonghua Wai Ke Za Zhi 2006, 44(2):97-9.

7. Tian $X L$, Feng RE, Shi JH, Duan MH, Wang JL, Liu HR, Cai BQ, Gao JM, Xu WB, Zhu YJ: Primary pulmonary lymphoma: analysis of 18 cases

8. Varona JF, Guerra JM, Grande C, Villena V, Gonzalez-Lois C, Martinez MA: Primary pulmonary lymphoma: diagnosis and follow up of 6 cases and review of an uncommon entity .

9. Peterson H, Snider HL, Yam LT, Bowlds CF, Arnn EH, Li CY: Primary pulmonary lymphoma. A clinical and immunohistochemical study of six cases. Cancer 1985, 56(4):805-13.

10. Muller C, Grivaux M, Schwattz F, Blanchon F: Primary pulmonary lymphoma. Current data. Apropos of 9 cases. Rev Pneumol Clin 1990, 46(4):166-71.

11. Mu XD, Wang GF, Diao XL, Que CL: A case of marginal zone B-cell lymphoma of the pulmonary mucosa- associated lymphoid tissue type. Beijing Da Xue Xue Bao 2007, 39(4):346-50.

12. Natali $F$, Merlet $P$, Le Vagueresse $R$, Allard $P$, Jourdain de Muizon $H$, Kermarec J: Primary pulmonary lymphoma. Rev Pneumol Clin 1984, 40(6):355-62.

13. Deng LP, Hu HJ, Zhang SZ, Dong DJ, Tan HQ: Radiological features of primary pulmonary non-Hodgkin lymphoma:report of three cases. Zhonghua Jie He He Hu Xi Za Zhi 2003, 26(4):223-6.

14. Nakachi S, Nagasaki A, Owan I, Uchihara T, Fujita J, Ohshima K, Miyagi T, Taira T, Taira N, Takasu N: Primary pulmonary Hodgkin lymphoma-two case reports and a review of the literature. Gan To Kagaku Ryoho 2007, 34(13):2279-82.

15. Martinez Rivera C, Bonnin Vilaplana M, Simon Adiego C, Palacin Forgue A, Puig Zuza J, Sampablo Lauro I: Primary pulmonary lymphoma presenting as a pulmonary mass with cavitation. Arch Bronconeumol 2004, 40(2):94-6.

16. Colby TV, Carrington CB: Pulmonary lymphomas simulating lymphomatoid granulomatosis. Am J Surg Pathol 1982, 6(1):19-32.

17. Toh HC, Ang PT: Primary pulmonary lymphoma-clinical review from a single institution in Singapore. Leuk Lymphoma 1997, 27(1-2):153-63.

18. Marchevsky A, Padilla M, Kaneko M, Kleinerman J: Localazed lymphoid nodules of the lung. A reappraisal of the lymphoma versus pseudolymphoma dilemma. Cancer 1983, 51(11):2070-7.

19. Morisako T, kobayashi H, Kanou S, Uwabe $Y$, Nagata N, Aoki T, Ozeki $Y$, Aida S, Tamai S: Clinicopathological study of six cases of primary pulmonary lymphoma diagnosed by gene rearrangement analysis. Nihon Kokyuki Gakkai Zasshi 1998, 36(3):236-40.

20. Kim JH, Lee SH, Park J, Kim HY, Lee SI, Park JO, Kim K, Kim WS, Jung CW, Park YS, Im YH, Kang WK, Lee MH, Park K, Han JH, Ko YH: Primary pulmonary non- Hodgkin lymphoma. Jpn J Clin Oncol 2004, 34(9):510-4.

21. Addis BJ, Hyjek E, Isaacson PG: Primary pulmonary lymphoma: a reappraisal of its histogenesis and its relationship to pseudolymphoma and lymphoid interstitial pneumonia. Histopathology 1988, 13(10):1-17.

22. Arinc S, Yilmaz A: Primary pulmonary lymphoma. Tuberk Toraks 2006, 54(2):197-202.

23. $X u$ HY, Jin T, Li RY, Ni YM, Zhou JY, Wen XH: Diagnosis and treatment of pulmonary mucosa-associated lymphoid tissue lymphoma. Chin Med J 2007, 120(8):648-51.

24. Pagani M, Antico A, Bellarosa S, Cavazzini G, Aitini E: Primary pulmonary high grade non-Hodgkin lymphoma in an elderly patient. A case report. Tumori 2007, 93(6):622-4.

25. Cao MS, Cai HR, Yin HL, Zhang DP, Xiao YL, Cao M, Dai L, Hou J: Primary natural killer/T cell lymphoma of the lung: two cases report and clinical analysis. Zhonghua Jie He He Hu Xi Za Zhi 2008, 31(2):120-4.

26. Baas $A A$, van Herwaarden CL: Primary non- Hodgkin lymphoma of the lung. Eur J Respir Dis 1986, 68(3):218-23.

27. Ziade N, Khayat G, Sader-Ghorra C, Abadjian G: Primary pulmonary lymphoma. A case report and review of the literature. J Med Liban 2005, 53(1):50-4

28. Habermann TM, Ryu JH, Inwards DJ, Kurtin PJ: Primary pulmonary lymphoma. Semin Oncol 1999, 26(3):307-15. 
29. Uematsu M, Okada M, Ishii N, Watanabe N, Yasufuku M: Surgical treatment of primary pulmonary malignant lymphoma: a report of successful case. Kyobu Geka 1997, 50(4):325-30.

30. Tillawi IS: Primary pulmonary Hodgkins lymphoma. A report of 2 cases and review of the literature. Saudi Med J 2007, 28(6):943-8.

31. Chu HQ, Ren SX, Yi XH: The clinical diagnosis and analysis of pulmonary mucosa associated lymphoid tissue lymphoma. Zhonghua Jie He He hu Xi Za Zhi 2007, 30(3):167-9.

32. Le Tourneau A, Audouin J, Garbe L, Capron F, Servais B, Monges G, Payan H, Diebold J: Primary pulmonary malignant lymphoma, clinical and pathological findings, immunocytochemical and ultrastructural studies in 15 cases. Hematol Oncol 1983, 1(1):49-60.

33. Loh KC, Chan KW, Sng I: Primary pulmonary lymphoma:report of three cases and a brief review of the literature. Ann Acad Med Singapore 1994 23(3):400-5.

34. Cordier JF, Bernaudin JF, Mary P, Guillaud C, Loire R, Brune J, Touraine R: Primary pulmonary pseudolymphomas and lymphomas.4 cases. Rev Mal Respir 1984, 1(2):105-11.

35. Watanabe J, Yamaguchi K, Sugiyama Y, Yotsumoto H, Takaku F: Primary pulmonary lymphoma demonstration of monoclonality by lymphocyte surface marker study. Jpn J Med 1987, 26(3):377-80.

36. Toishi M, Miyazawa M, Takahashi K, Hyogotani A, Haba Y, Kato K, Muramatsu A, Nishiyama M, Ozawa K, Nanbu A, Miyata K: Mucosaassociated lymphoid tissue lymphoma; report of two cases. Kyobu Geka 2004, 57(1):75-9.

37. Jayet $\mathrm{A}$, Wertheim U, Crausaz PH, Saegesser F: Pulmonary granuloma, pseudolymphoma and lymphoma. Helv Chir Acta 1980, 47(1-2):37-40

38. Kuroishi S, Nakano Y, Ono T, Shirai m, Hayakawa H, Murakami M, Suda T, Chida K, Nakamura H, Kobashi Y: A case of primary pulmonary MALT lymphoma as a nodular shadow on CT scan, and relapsed with diffuse micronodular shadows after surgical resection at 7 years ago. Nihon Kokyuki Gakkai Zasshi 2003, 41(12):922-7.

39. Sakula A: Primary malignant lymphoma of lung. Postgrad Med J 1979, 55(639):46-9.

40. Hashizume T, Honda A, Eto T, Akiyama J, Yamakawa H, Ikehara K, Ito M, Fujii M, Suzuki M, Arai K: Primary pulmonary lymphoma diagnosed from monoclonality of lymphocytes in a transbronchial biopsy specimen. Nihon Kyobu Shikkan Gakkai Zasshi 1997, 35(1):95-9.

41. Gouldesbrough DR, McGoogan E: Primary pulmonary lymphoma: a case diagnosed by bronchial cytology and immunocytochemistry. Histopathology 1988, 13(4):465-7.

42. Bosanko CM, Korobkin M, Fantone JC, Rubin SB, Lynch JP: Lobar primary pulmonary lymphoma: CT findings. I Comput Assist Tomogr 1991, 15(4):679-82.

43. Chee YC, Yap CH, Poh SC: Pulmonary lymphoma or pseudolymphoma: a diagnostic dilemma. Ann Acad Med Singapore 1986, 15(1):113-7.

44. Bolton- Maggs PH, Colman A, Dixon GR, Myskow MW, Williams JG, Donnelly RJ, Hind CR: Mucosa associated lymphoma of the lung. Thorax 1993, 48(6):670-2.

45. Xu TR: Pulmonary lymphoma of mucosa-associated lymphoid tissue. A clinical, pathological, immunochemical and ultrastructural study of 2 cases. Zhonghua Jie He He Hu Xi Za Zhi 1987, 10(5):269-70.

46. Konig G, Huhn D, Albrecht J: Diagnosis of pulmonary manifestations of malignant lymphoma by bronchopulmonary lavage. Prax Klin Pneumol 1986, 40(5):183-5.

47. Ehrenstein F: Primary pulmonary lymphoma. Review of the literature and two case reports. J Thorac Cardiovasc Surg 1966, 52(1):31-9.

48. Tamura A, Komatsu H, Yanai N, Homma J, Nagase A, Nemoto E, Hirai T, Hashizume T, Kawata K, Ishikawa S: Primary Pulmonary Lymphoma: relationship between clinical features and pathological finings in 24 cases. The Japan National Chest Hospital Study Group for Lung Cancer. Jpn J Clin Oncol 1995, 25(4):140-52.

49. Sakuraba M, Onuki T, Mae M, Yoshida T, Nitta S: Three cases of primary pulmonary malignant lymphoma. Nihon Kokyuki Gakkai Zasshi 2000, 38(9):714-9.

50. Abe Y, Hayashi A, Yasufuku K, Oiwa T, Kurosu K, Mikata A: Nihon Kokyuki Gakkai Zasshi 1998, 36(4):403-7.

51. Umino T, Ohdama S, Sawada M, Tachibana S, Takano S, Miyake S, Aoki N, Yamamoto N, Matsubara O, Masuda S: A case of surgically resected primary pulmonary lymphoma with IgG-paraproteinemia: gene analysis was effective for establishing its diagnosis. Nihon Kokyuki Gakkai Zasshi 1993, 31(8):1012-8.

52. Zinzani PL, Tani M, Gabriele A, Poletti V, Stefoni V, Alinari L, Musuraca G, Bonifazi F, Pileri S, Tura S, Baccarani M: Extranodal marginal zone B-cell lymphoma of MALT type of the lung: Single center experience with 12 patients. Leuk Lymphoma 2003, 44(5):821-4.

53. Herbert A, Wright $D H$, Isaacson $P G$, Smith JL: Primary malignant lymphoma of the lung:histopathologic and immunologic evaluation of nine cases. Hum Pathol 1984, 15(5):415-22.

54. Davis WB, Gadek JE: Detection of pulmonary lymphoma by bronchoalveolar lavage. Chest 1987, 91(5):787-90.

55. Pisani RJ, Witzig TE, Li CY, Morris MA, Thibodeau SN: Confirmation of lumphomatous pulmonary involvement by immunophenotypic and gene rearrangement analysis of bronchoalveolar lavage fluid. Mayo Clin Proc 1990, 65(5):651-6.

56. Sprague Rl, deBlois GG: Small lymphocytic pulmonary lymphoma. Diagnosis by transthoracic fine needle aspiration. Chest 1989, 96(4):929-30.

57. Julsrud PR, Brown LR, Li CY, Rosenow EC, Crowe JK: Pulmonary processes of mature-appearing lymphocytes: pseudolymphoma, well-differentiated lymphocytic lymphoma and lymphocytic interstitial pneumonitis. Radiology 1978, 127(2):289-96.

58. Lewis ER, Caskey Cl, Fishman EK: Lymphoma of the lung:CT findings in 31 patients. AJR Am J Roentgenol 1991, 156(4):711-4.

59. Bellotti M, Elsner B, Esteva H, Mackinlay TA, Mazzei JA: Fiberoptic bronchoscopy in the diagnosis of pulmonary lymphomas. Respiration 1987, 52(3):201-4.

60. Kilgore TL, Chasen MH: Endobronchial non-Hodgkins lymphoma. Chest 1983, 84(1):58-61.

61. Rose RM, Grigas D, Strattemeir E, Harris NL, Linggood RM: Endobronchial involvement with non-Hodgkins lymphoma. A clinical -radiological analysis. Cancer 1986, 57(9):1750-5.

62. Oka M, Kawano K, Kanda T, Hara K: Bronchoalveolar lavage in primary pulmonary lymphoma with monoclonal gammopathy. Am Rev Respir Dis 1988, 137(4):957-9.

63. Koss MN, Hochholzer L, Nichols PW, Wehunt WD, Lazarus AA: Primary nonHodgkins lymphoma and pseuolymphoma of lung: a study of 161 patients. Hum Pathol 1983, 14(12):1024-38.

64. Turner RR, Colby TV, Doggett RS: Well-differentiated lymphocytic lymphoma. A study of 47 patients with primary manifestation in the lung. Cancer 1984, 54(10):2088-96.

65. L Hoste R Jr, Filippa D, Lieberman P, Bretsky S: Primary Pulmonary Lymphomas. A clinicopathologic analysis of 36 cases. Cancer 1984, 54:1397-1406.

66. Kennedy JL, Nathwani BN, Burke JS, Hill LR, Rappaport H: Pulmonary lymphomas and other pulmonary lymphoid lesions. A clinicopathologic and immunologic study of 64 patients. Cancer 1985, 56(3):539-52.

67. Li G, Hansmann ML, Zwingers T, Lennert K: Primary lymphomas of the lung: morphological, immunohistochemical and clinical features. Histopathology 1990, 16(6):519-31.

68. Cordier JF, Chailleux E, Lauque D, Reynauld-Gaubert M, DietemannMolard A, Dalphin JC, Blanc-Jouvan F, Loire R: Primary pulmonary lymphomas. A clinical study of 70 cases in nonimmunocompromised patients. Chest 1993, 103:201-208.

69. Ferraro P, Trastek V, Adlakha H, Deschamps C, Allen M, Pairolero P: Primary non Hodgkins lymphoma of the lung. Ann Thorac Surg 2000, 69:993-997.

70. Graham BB, Mathisen DJ, Mark EJ, Takvorian RW: Primary pulmonary lymphoma. Ann Thorac Surg 2005, 80(4):1248-53.

71. Hu YH, Hsiao LT, Yang CF, Chiou TJ, Liu JH, Gau JP, Yen CC, Chou TY, Hsu WH, Chen PM, Tzeng CH: Prognostic factors of Chinese patients with primary pulmonary non-Hodgkins lymphoma: the single-institude experience in Taiwan. Ann Hematol 2009.

72. Bienenstock J, Johnston N, Perey D: Bronchial lymphoid tissue. Lab Invest 1973, 28:686-98.

73. Harris NL, Jaffe ES, Stein $\mathrm{H}$, et al: A revised European- American classification of lymphoid neoplasms: a proposal from the InternationalLymphoma Study Group. Blood 1994, 84:1361-92.

doi:10.1186/1749-8090-6-23

Cite this article as: Parissis: Forty years literature review of primary lung lymphoma. Journal of Cardiothoracic Surgery 2011 6:23. 